\title{
Impact of diatomite addition on lead immobilization in air pollution control residues from a municipal solid waste incinerator
}

\author{
Hiroki Kitamura ${ }^{1}$ (D) Masato Ueshima ${ }^{2} \cdot$ Seungki Back ${ }^{1} \cdot$ Noppharit Sutthasil $^{1} \cdot$ Hirofumi Sakanakura ${ }^{1}$. \\ Tomonori Ishigaki ${ }^{1} \cdot$ Masato Yamada ${ }^{1}$
}

Received: 29 April 2021 / Accepted: 30 October 2021 / Published online: 9 November 2021

(C) The Author(s) 2021

\begin{abstract}
Air pollution control (APC) residues, which are known to be the byproducts of incineration treatment, exhibit a high leaching potential of toxic metals. Calcium silicate hydrate $(\mathrm{C}-\mathrm{S}-\mathrm{H})$, which is a major hydration product of hardened cement and immobilizes toxic metal, can be formed by the reaction of $\mathrm{Ca}$ with pozzolanic $\mathrm{Si}$ in a highly alkaline environment. Toxic metals might be immobilized by the addition of pozzolanic material to APC residues (instead of using cement), which is a Ca source and provides an alkaline condition. In this study, diatomite, which mainly comprises amorphous silica $\left(\mathrm{SiO}_{2} \cdot \mathrm{nH}_{2} \mathrm{O}\right)$, was investigated as a pozzolanic material for $\mathrm{Pb}$ immobilization in APC residues obtained from a municipal solid waste incinerator. APC residues were cured with and without the addition of diatomite at different temperatures. When diatomite was added to APC residues, pozzolanic phases such as C-S-H gel were formed via the consumption of $\mathrm{Ca}(\mathrm{OH})_{2}$ and $\mathrm{CaClOH}$. Compared to APC residues cured without diatomite, the leaching of $\mathrm{Pb}$ decreased by $99 \%$ for APC residues cured for 14 days with $10 \%$ diatomite at $70{ }^{\circ} \mathrm{C}$. The results of sequential chemical extraction showed that water-soluble $\mathrm{Pb}$ in APC residues was reduced from $10.3 \%$ to nearly zero by the pozzolanic reaction. Consequently, the leaching amount of $\mathrm{Pb}$ dropped below $0.3 \mathrm{mg} / \mathrm{L}$ (Japanese criteria for landfill disposal). Overall, these experiments provide promising results regarding the possibility of using diatomite for pretreating APC residues.
\end{abstract}

Keywords Municipal solid waste $\cdot$ Air pollution control residues $\cdot$ Metal immobilization $\cdot$ Diatomite $\cdot$ Pozzolanic reaction

\section{Introduction}

Municipal solid waste incineration (MSWI) has been initiated for hygienic control (Gohlke and Martin 2007). New landfill construction is complicated by the "not in my backyard" (NIMBY) syndrome and limited availability of space (Asakura et al. 2010). Owing to volume and mass reduction, incineration is the most common treatment for municipal solid waste (MSW) (Lombardi et al. 2015). Even after reduction, MSWI residues (bottom ash and air pollution

Responsible Editor: Philippe Garrigues

Hiroki Kitamura

kitamura.hiroki@nies.go.jp

1 Material Cycles Division, National Institute for Environmental Studies, 16-2 Onogawa, Tsukuba, Ibaraki 305-8506, Japan

2 R\&D Center, Yoshino Gypsum Co., LTD, 2-1-1 Kohoku, Adachi-ku, Tokyo 123-0872, Japan control (APC) residues) continue to be byproducts of incineration treatment. Bottom ash and APC residues account for $10-15 \%$, and $2-3 \%$ of the weight of MSW, respectively (Chang and Wey 2006). Furthermore, MSWI residues contain toxic metals (Jung et al. 2004). In particular, the leachability of toxic metals in APC residues is higher than that in bottom ash (Kida et al. 1996; Song et al. 2004). Because of the high leaching potential of toxic metals, pretreatments of APC residues are required in many countries to prevent the release of toxic metals into the environment (Quina et al. 2008). The available treatments for APC residues can be categorized into three groups: (1) physical or chemical separation, (2) solidification/stabilization (S/S), and (3) thermal treatment (Van Der Sloot et al. 2001). Separation treatments aim to reduce the toxic metals and/or soluble salts from the residues via washing and leaching among other processes (Quina et al. 2008; Zacco et al. 2014). Solidification/stabilization $(\mathrm{S} / \mathrm{S})$ treatments produce a material with physical (specific surface area, porosity, etc.), mechanical (durability, mechanical strength, etc.), and chemical properties that 
can immobilize the hazardous species in waste (Zacco et al. 2014). Thermal treatments reduce leaching and the volume of residues, thereby producing a material that is suitable for reuse (Zacco et al. 2014).

Among these treatments, cement-based S/S is commonly used for metal immobilization in APC residues worldwide (Polettini et al. 2001; Benassi et al. 2016). Calcium silicate hydrate (C-S-H), which features high microporosity and a large surface area, is a major hydration product of hardened cement pastes (Gougar et al. 1996). In cementbased $\mathrm{S} / \mathrm{S}$ processes, $\mathrm{C}-\mathrm{S}-\mathrm{H}$ gel is formed by pozzolanic reactions between amorphous silica $\left(\mathrm{SiO}_{2} \cdot \mathrm{nH}_{2} \mathrm{O}\right)$ and calcium hydroxide $\left(\mathrm{Ca}(\mathrm{OH})_{2}\right)$ (Dermatas et al. 2005). C-S-H gel can immobilize toxic metals via sorption, incorporation, and encapsulation (Chen et al. 2009). Based on the mechanism of the pozzolanic reaction, cement is not a necessity for $\mathrm{C}-\mathrm{S}-\mathrm{H}$ gel formation. If $\mathrm{C}-\mathrm{S}-\mathrm{H}$ gel can be formed using inexpensive materials instead of cement, the treatment cost would be reduced. Dissolved amorphous silica in the presence of $\mathrm{Ca}$ ions is required for the formation of C-S-H gel. The solubility of amorphous silica increases at alkaline $\mathrm{pH}$ (Alexander et al. 1954). APC residues usually contain high amounts of $\mathrm{Ca}$ as a sorbent and reactant for the removal of acidic components in exhaust gas (Wang et al. 2010). APC residues often show high $\mathrm{pH}$ due to the presence of alkaline Ca compounds (Shim et al. 2005; Karlfeldt Fedje et al. 2010). Owing to the high Ca content and alkaline $\mathrm{pH}$, the addition of amorphous silica to APC residues may induce C-S-H gel formation via pozzolanic reactions for metal immobilization. Recently, diatomite has received increasing attention as a natural pozzolanic material owing to its high amorphous silica content (Kastis et al. 2006; Ergün 2011), relative abundance (Xu et al. 2016), and low cost compared to Portland cement ( $\mathrm{Li}$ et al. 2019). Diatomite is a sedimentary rock composed mainly of skeletons of individual diatoms, which are unicellular microscopic plants. In cementbased $\mathrm{S} / \mathrm{S}$ processes, other cement hydrates such as ettringite $\left(3 \mathrm{CaO} \cdot \mathrm{Al}_{2} \mathrm{O}_{3} \cdot 3 \mathrm{CaSO}_{4} \cdot 32 \mathrm{H}_{2} \mathrm{O}\right)$ are also formed. Ettringite can incorporate toxic metals into its structure $\left(\mathrm{Ca}^{2+}, \mathrm{Al}^{3+}\right.$, and $\mathrm{SO}_{4}{ }^{2-}$ sites) by substitution reactions (Gougar et al. 1996). Because the main components of APC residues are similar to those in cement (Liu et al. 2018), cement hydrates can be formed in APC residues without cement addition (Montagnaro et al. 2003). Although it is unclear whether other cement hydrates except C-S-H gel contribute to metal immobilization in actual systems (Geysen et al. 2004), the mineralogical characteristics of APC residues might have the potential for metal immobilization without using cement.

In this context, this study aims to investigate the feasibility of using diatomite on metal immobilization (particularly for $\mathrm{Pb}$ ) in APC residues instead of using cement. Lead immobilization, which occurs due to $\mathrm{C}-\mathrm{S}-\mathrm{H}$ gel formation after diatomite addition, was mainly investigated along with the impacts of secondary mineral formation. In this study, the conditions for $\mathrm{Pb}$ immobilization, such as doses of diatomite, curing temperature, and curing time, were investigated. The effect on $\mathrm{Pb}$ immobilization was evaluated by the Japanese leaching test to determine the leachabilities of toxic metals from wastes and to determine whether the waste is hazardous. The mineralogical characteristics of APC residues and the chemical form of $\mathrm{Pb}$ which changed following diatomite addition were also investigated.

\section{Materials and methods}

\section{Air pollution control residue sample and diatomite}

An APC residue sample was collected from the bag filter of a stoker-type incinerator in Japan. The incineration capacity was 80 tons/day. The incinerator is equipped with a dry scrubbing system using slaked lime $\left(\mathrm{Ca}(\mathrm{OH})_{2}\right)$ to neutralize the acidic components ( $\mathrm{HCl}$ and $\mathrm{SOx})$ in the flue gas. The unreacted slaked lime and/or the reaction products in the APC residue sample could be used as Ca sources for the pozzolanic reaction.

Amorphous silica was essential for the pozzolanic reaction in this study. Diatomite containing amorphous silica in the presence of $\mathrm{Ca}$ in APC residues promotes $\mathrm{C}-\mathrm{S}-\mathrm{H}$ gel formation. Although reagent-grade diatomite is sometimes calcinated owing to the removal of impurities such as organic matter and carbonate compounds from raw diatomite (Ren et al. 2014), the amorphous silica phase is transformed into a crystalline phase such as cristobalite $\left(\mathrm{SiO}_{2}\right)$ by calcination (Zheng et al. 2018). For this reason, non-calcinated diatomite (DiatomaceousEarth.com, USA) was selected as a pozzolanic material for the formation of C-S-H gel.

\section{Characterization of air pollution control residue sample and diatomite}

The chemical compositions of the APC residue sample and diatomite were analyzed using a wavelength dispersive $\mathrm{X}$-ray fluorescence spectrometer (XRF: ZSX Primus II, Rigaku Co., Japan). The XRF results were obtained in oxide form and then converted into elemental form (mass\%). The mineral compositions were determined via X-ray diffraction (XRD; MultiFlex, Rigaku Co., Japan). The measurement conditions for XRD analysis were as follows: $40 \mathrm{kV}$ accelerating voltage, $26 \mathrm{~mA}$ current, $5-75^{\circ} 2 \theta$ scanning range, $0.01^{\circ}$ step, and $1 \%$ min scan speed. Morphological characteristics were observed using a field emission scanning electron microscope (FE-SEM, JSM-7800F, JEOL Ltd., Japan) under low-vacuum conditions. The elemental composition of each APC residue particle was analyzed by energy-dispersive $\mathrm{X}$-ray (EDX) attached to SEM (SEM-EDX: X-Max ${ }^{\mathrm{N}} 50$, 
Oxford Instruments, UK). The leachability of regulated toxic metals (As, $\mathrm{Cd}, \mathrm{Cr}, \mathrm{Pb}$, and $\mathrm{Se}$ ) from APC residues was investigated using the Japanese leaching test. First, $20 \mathrm{~mL}$ of distilled water was added to $2 \mathrm{~g}$ of APC residue in a polypropylene bottle (liquid to solid ratio $=10$ ). The bottle was shaken horizontally at a rate of 200 times per minute with an amplitude of $5 \mathrm{~cm}$ for $6 \mathrm{~h}$. After shaking, the bottle was centrifuged at $3000 \mathrm{rpm}$ for $20 \mathrm{~min}$. The supernatant was filtered through a cellulose acetate membrane filter with a $0.45-\mu \mathrm{m}$ pore size. The concentrations of toxic metals in the leachate were measured by inductively coupled plasma mass spectrometry (ICP-MS; 720 ICP-MS, Agilent Technologies, USA) and inductively coupled plasma optical emission spectroscopy (ICP-OES: 7500CX ICP-MS, Agilent Technologies, USA).

\section{Immobilization of lead in air pollution control residues by curing}

Diatomite accounting for $0 \%, 5 \%$, and $10 \%$ with respect to weight was added to $30 \mathrm{~g}$ of APC residues at different doses. Subsequently, $22.5 \mathrm{~mL}$ of distilled water was added. The mixture was kneaded using a mixer (DLC-1 J, Cuisinart, USA) to create a paste. The paste was wrapped in a thin plastic sheet and stored in a sealed plastic bottle to maintain moist conditions, and subsequently cured at 25 , 50 , or $70{ }^{\circ} \mathrm{C}$ for 14 days. After $1,2,4,7$, and 14 days, the cured APC residues were dried in a desiccator using a drying agent (silica gel) at $25^{\circ} \mathrm{C}$. After drying, the cured APC residue was subjected to $\mathrm{XRD}$ analysis, SEM observation, and the leaching test described in the "Characterization of air pollution control residue sample and diatomite" section. The chemical form of $\mathrm{Pb}$ was estimated by sequential chemical extraction modified from the method suggested by Tessier et al. (1979). Raw APC residues and cured APC residues, which yielded the lowest leaching concentration of $\mathrm{Pb}$ in this study, were subjected to sequential chemical extraction. Table 1 shows the fractional patterns with the extraction methods. The sequence of fractional patterns is as follows: (F1) water-soluble, (F2) exchangeable, (F3) bound to carbonates, (F4) bound to metal oxides, (F5) bound to organic matter, and (F6) residual. The concentration of $\mathrm{Pb}$ in each fractionated extract solution was measured, and the results were given as the ratio of the total amount of $\mathrm{Pb}$ in each solution. Sequential chemical extraction suggested by Tessier et al. (1979) was originally developed for soils and sediments. Although sequential chemical extraction has been widely applied to MSWI residues, its results may not necessarily reflect associations with the target fractions (Wan et al. 2006; Funatsuki et al. 2012).

\section{Results and discussion}

\section{Basic characteristics of diatomite and air pollution control residue sample}

Table 2 shows the chemical compositions of diatomite determined by XRF analysis. The results showed that diatomite consists mainly of Si (42.5 mass\%) and minor compositions such as $\mathrm{Al}$ and $\mathrm{Fe}(2.77$ mass\% and 0.96 mass\%, respectively). Figure 1 shows the XRD pattern of diatomite. A

Table 1 Procedures of sequential chemical extraction

\begin{tabular}{|c|c|}
\hline Fraction & Procedure \\
\hline F1 Water soluble & $10 \mathrm{~g}$ (dry weight) of sample was shaken for $6 \mathrm{~h}$ at room temperature with $100 \mathrm{~mL}$ of purified water \\
\hline F2 Exchangeable & The residue from $\mathrm{F} 1 \mathrm{was}$ shaken for $18 \mathrm{~h}$ at room temperature with $100 \mathrm{~mL}$ of $1.0 \mathrm{~mol} / \mathrm{L} \mathrm{CH}_{3} \mathrm{COONH}_{4}$ \\
\hline F3 Bound to carbonates & $\begin{array}{l}\text { The residue from } \mathrm{F} 2 \text { was shaken for } 18 \mathrm{~h} \text { at room temperature with } 100 \mathrm{~mL} \text { of } 1.0 \mathrm{~mol} / \mathrm{L} \mathrm{CH}_{3} \mathrm{COONa} \text { adjusted } \\
\text { to } \mathrm{pH} 5 \text { with } \mathrm{CH}_{3} \mathrm{COOH}\end{array}$ \\
\hline F4 Bound to metal oxides & $\begin{array}{l}\text { The residue from } \mathrm{F} 3 \text { was shaken for } 18 \mathrm{~h} \text { at } 85^{\circ} \mathrm{C} \text { with } 100 \mathrm{~mL} \text { of } 0.2 \mathrm{~mol} / \mathrm{L} \mathrm{NH} \mathrm{NH}_{2} \mathrm{OH} \cdot \mathrm{HCl} \mathrm{with} \mathrm{CH}{ }_{3} \mathrm{COOH} \text { in } \\
25 \mathrm{vol} / \mathrm{vol} \%\end{array}$ \\
\hline F5 Bound to organic matters & $\begin{array}{l}\text { The residue from } \mathrm{F} 4 \text { was shaken for } 2 \mathrm{~h} \text { at } 85^{\circ} \mathrm{C} \text { with } 30 \% \mathrm{H}_{2} \mathrm{O}_{2} \text { adjusted to } \mathrm{pH} 2 \text { with } 0.02 \mathrm{~mol} / \mathrm{L} \mathrm{HNO}_{3} \text {. } \\
\text { After cooling, } 100 \mathrm{~mL} \text { of } 1.78 \mathrm{~mol} / \mathrm{L} \mathrm{CH}_{3} \mathrm{COONH}_{4} \text { with } \mathrm{HNO}_{3} \text { in } 11.1 \mathrm{vol} / \mathrm{vol} \% \text { was added and the sample } \\
\text { was agitated for } 30 \mathrm{~min}\end{array}$ \\
\hline F6 Residual & $\begin{array}{l}2.5 \mathrm{~mL} \text { of concentrated } \mathrm{HNO}_{3} \text { and } 7.5 \mathrm{~mL} \text { of concentrated } \mathrm{HCl} \text { were added to } 0.2 \mathrm{~g} \text { (dry wight) of residue from } \\
\mathrm{F} 5 \text { and heated at } 120{ }^{\circ} \mathrm{C} \text { covered with a watch glass. The sample was filtrated using a } 5 \mathrm{~B} \text { filter in order to } \\
\text { obtain supernatant }\end{array}$ \\
\hline
\end{tabular}

Table 2 Chemical compositions of diatomite determined by X-ray fluorescence (XRF) analysis

\begin{tabular}{|c|c|c|c|c|c|c|c|c|c|c|c|c|}
\hline Elements & $\mathrm{Si}$ & $\mathrm{Al}$ & $\mathrm{Fe}$ & $\mathrm{Ca}$ & $\mathrm{Mg}$ & $\mathrm{Ti}$ & $\mathrm{Na}$ & $\mathrm{K}$ & S & $\mathrm{P}$ & $\mathrm{Cl}$ & $\mathrm{O}$ \\
\hline mass $\%$ & 42.5 & 2.77 & 0.96 & 0.62 & 0.37 & 0.21 & 0.15 & 0.16 & 0.013 & 0.0090 & 0.0092 & 52.1 \\
\hline
\end{tabular}




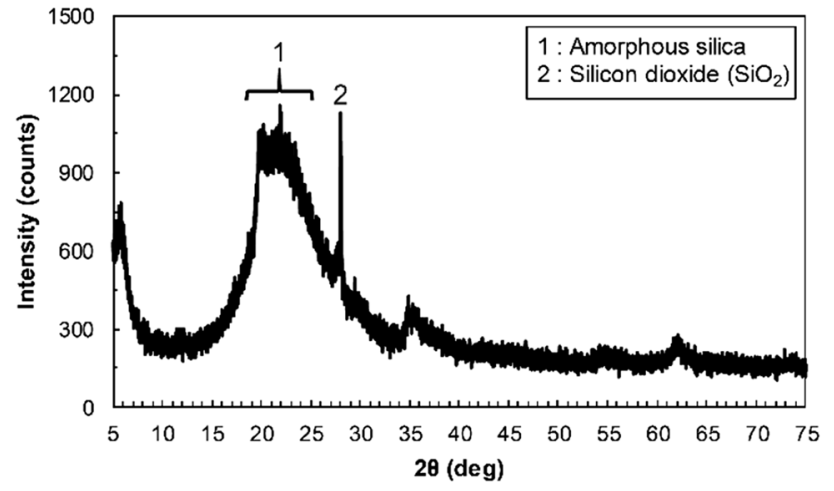

Fig. 1 X-ray diffraction (XRD) pattern of diatomite

broad peak (hump) of amorphous silica and a peak of silicon dioxide were observed as reported by other studies (Sierra et al. 2010; Ergün 2011). Figure 2 shows the backscattered electron image of diatomite and the elemental spectrum. Diatomite shows a cylindrical and porous structure containing Si.

According to $\mathrm{XRF}$ analysis, $\mathrm{Ca}$ and $\mathrm{Cl}$ were the two dominant elements of the APC residue sample, accounting for $36.4 \%$ and $32.7 \%$ of the mass, respectively (Table 3). Toxic metals such as $\mathrm{Cd}, \mathrm{Cr}$, and $\mathrm{Pb}$ were also identified as minor elements. Figure 3 shows the XRD pattern of the APC residue sample. The results showed that the APC residue sample mainly comprised Ca-bearing minerals and inorganic salts such as sylvite $(\mathrm{KCl})$ and halite $(\mathrm{NaCl})$. The high $\mathrm{Ca}$ content determined by XRF analysis was attributed to Ca-bearing minerals such as portlandite $\left(\mathrm{Ca}(\mathrm{OH})_{2}\right)$, calcium chloride hydroxide $(\mathrm{CaClOH})$, anhydrite $\left(\mathrm{CaSO}_{4}\right)$, and calcite $\left(\mathrm{CaCO}_{3}\right)$, whereas the high $\mathrm{Cl}$ content was attributed to $\mathrm{CaClOH}, \mathrm{KCl}$, and $\mathrm{NaCl}$. Portlandite is an unreacted slaked lime that is sprayed for acidic gas treatment. Calcium chloride hydroxide is formed during the acidic gas $(\mathrm{HCl})$ neutralization process (Eqs. (1)-(3)) (Jozewicz and Gullett 1995). Anhydrite is also formed by the neutralization of SOx (Eq. (4)) (Bodénan and Deniard 2003). Calcite is formed from portlandite via carbonation by atmospheric moisture and $\mathrm{CO}_{2}$ (Eq. (5)) (Weibel et al. 2016). Substances with high vapor pressures and low boiling points, such as alkali and volatile metals, undergo volatilization and transfer to flue gas during the incineration process (Weibel et al. 2016). Cooling of flue gas promotes the formation of alkali metal chlorides such as $\mathrm{KCl}$ and $\mathrm{NaCl}$ because the chemical potential of $\mathrm{Cl}, \mathrm{K}$, and $\mathrm{Na}$ exceeds that of volatile metals (Chiang et al. 1997; Durlak et al. 1997).

$\mathrm{Ca}(\mathrm{OH})_{2}+2 \mathrm{HCl} \rightarrow \mathrm{CaCl}_{2}+2 \mathrm{H}_{2} \mathrm{O}$

$\mathrm{Ca}(\mathrm{OH})_{2}+\mathrm{HCl} \rightarrow \mathrm{CaClOH}+\mathrm{H}_{2} \mathrm{O}$

$\mathrm{Ca}(\mathrm{OH})_{2}+\mathrm{CaCl}_{2} \rightarrow 2 \mathrm{CaClOH}$

$\mathrm{Ca}(\mathrm{OH})_{2}+\mathrm{SO}_{2}+1 / 2 \mathrm{O}_{2} \rightarrow \mathrm{CaSO}_{4}+\mathrm{H}_{2} \mathrm{O}$
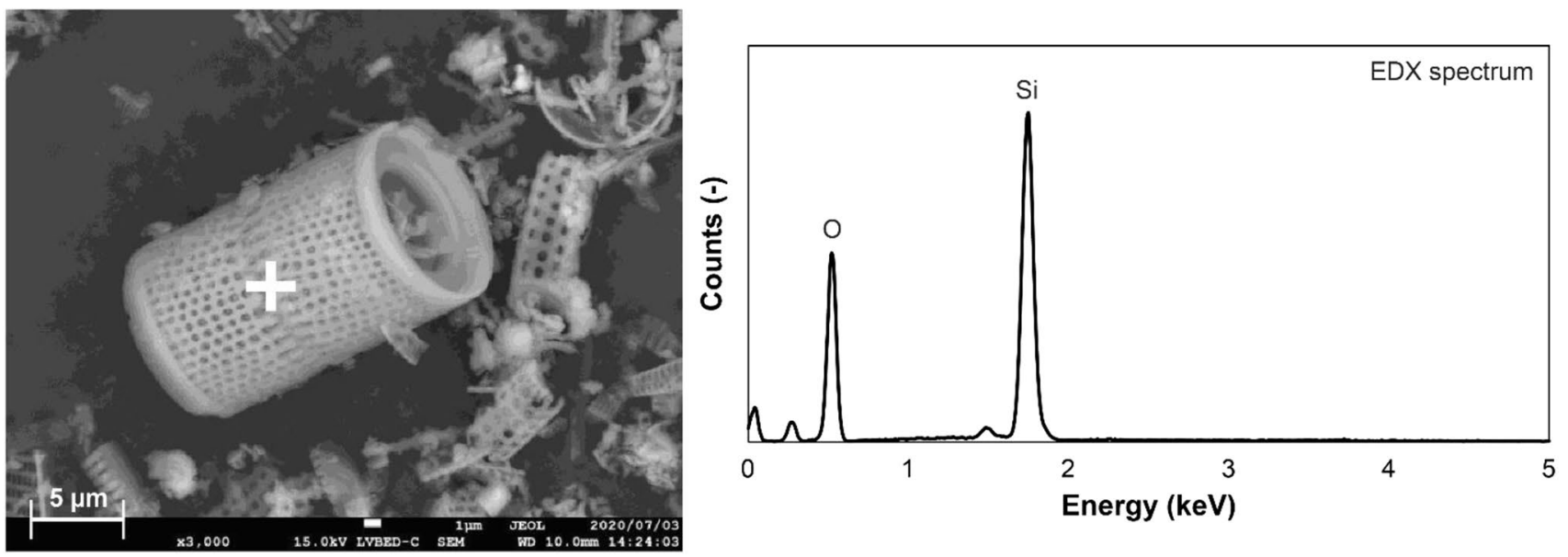

Fig. 2 Scanning electron microscopy (SEM) image and elemental spectrum of diatomite (white cross mark; analysis point)

Table 3 Chemical compositions of the air pollution control (APC) residue sample determined by XRF analysis

\begin{tabular}{llllllllllll}
\hline Elements & $\mathrm{Ca}$ & $\mathrm{Cl}$ & $\mathrm{Na}$ & $\mathrm{S}$ & $\mathrm{K}$ & $\mathrm{Si}$ & $\mathrm{Al}$ & $\mathrm{Mg}$ & $\mathrm{Fe}$ & $\mathrm{Zn}$ & $\mathrm{Ti}$ \\
\hline mass \% & 36.4 & 32.7 & 3.93 & 1.34 & 1.86 & 0.62 & 0.40 & 0.38 & 0.33 & 0.31 & 0.23 \\
Elements & $\mathrm{P}$ & $\mathrm{Br}$ & $\mathrm{Cd}$ & $\mathrm{Pb}$ & $\mathrm{Ba}$ & $\mathrm{Cu}$ & $\mathrm{Ag}$ & $\mathrm{Sr}$ & $\mathrm{Mn}$ & $\mathrm{Cr}$ & $\mathrm{O}$ \\
mass \% & 0.14 & 0.17 & 0.12 & 0.10 & 0.051 & 0.049 & 0.053 & 0.030 & 0.023 & 0.016 & 20.2 \\
\hline
\end{tabular}




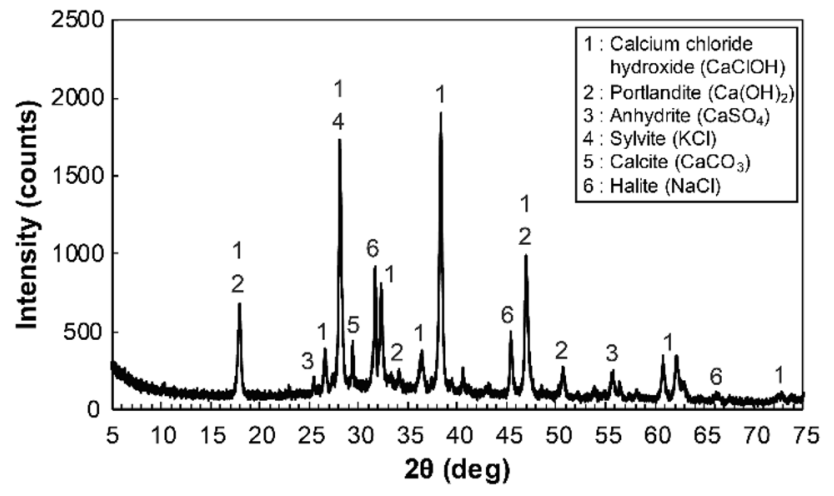

Fig. 3 XRD pattern of the air pollution controlled (APC) residue sample

$\mathrm{Ca}(\mathrm{OH})_{2}+\mathrm{CO}_{2} \rightarrow \mathrm{CaCO}_{3}+\mathrm{H}_{2} \mathrm{O}$

Figure 4 shows the backscattered electron image of the APC residue particles and elemental spectra. According to SEM observations, the APC residue sample showed larger particles (several tens of micrometers) with smooth surfaces and aggregates of smaller particles (several micrometers) as the main morphological structures. According to SEM-EDX analysis, larger particles contained $\mathrm{Ca}, \mathrm{O}$, and $\mathrm{Si}$ among other elements. These glasses are produced from melt droplets during the MSWI process (Bayuseno and Schmahl 2011). Aggregates of smaller particles, which consist mainly of $\mathrm{Ca}, \mathrm{Cl}$, and $\mathrm{O}$, are considered unreacted slaked lime $\left(\mathrm{Ca}(\mathrm{OH})_{2}\right)$ and the reaction product $(\mathrm{CaClOH})$ from the acidic gas neutralization process.
Table 4 shows the results of the leaching tests of APC residues. The $\mathrm{pH}$ value of the leachate was 12.0, which is close to the $\mathrm{pH}$ value of the saturated $\mathrm{Ca}(\mathrm{OH})_{2}$ solution (12.4). The results also exhibited the leaching of a considerable amount of $\mathrm{Pb}(11.7 \mathrm{mg} / \mathrm{L})$. Among the regulated toxic metals in Japan, volatile metals such as $\mathrm{Cd}$ and $\mathrm{Pb}$ are enriched in APC residues (Fernandez et al. 1992). The distribution of As in MSWI residues varies according to the combustion conditions (Jung et al. 2004). The concentration of Se is very low compared to that of other volatile metals (Jung et al. 2004). Chromium mainly remains in the bottom ash because Cr compounds are not thermally mobile during incineration (Jung et al. 2004). Among these regulated toxic metals, $\mathrm{Pb}$ is the most problematic owing to its high leachability (Quina et al. 2010). This study focused on $\mathrm{Pb}$ immobilization from the viewpoint of leaching potential.

\section{Impact of curing of air pollution control residues on lead immobilization}

Figure 5 shows the leaching concentration of $\mathrm{Pb}$ from cured APC residues and the $\mathrm{pH}$ of the leachate. Since an increase in curing temperature accelerates the early hydration reaction of cementitious materials (Greenberg 1961; Escalante-García and Sharp 1998), Pb leaching from cured APC residues decreased as curing time and temperature increased. At each curing temperature, $\mathrm{Pb}$ leaching from the cured APC residues decreased as diatomite doses increased. In APC residues cured without diatomite (blue lines in Fig. 5), the leaching amount of $\mathrm{Pb}$ after 14 days of curing was reduced by $18-67 \%$ from raw APC residues (11.7 mg/L). This means that $\mathrm{Pb}$ leaching was decreased
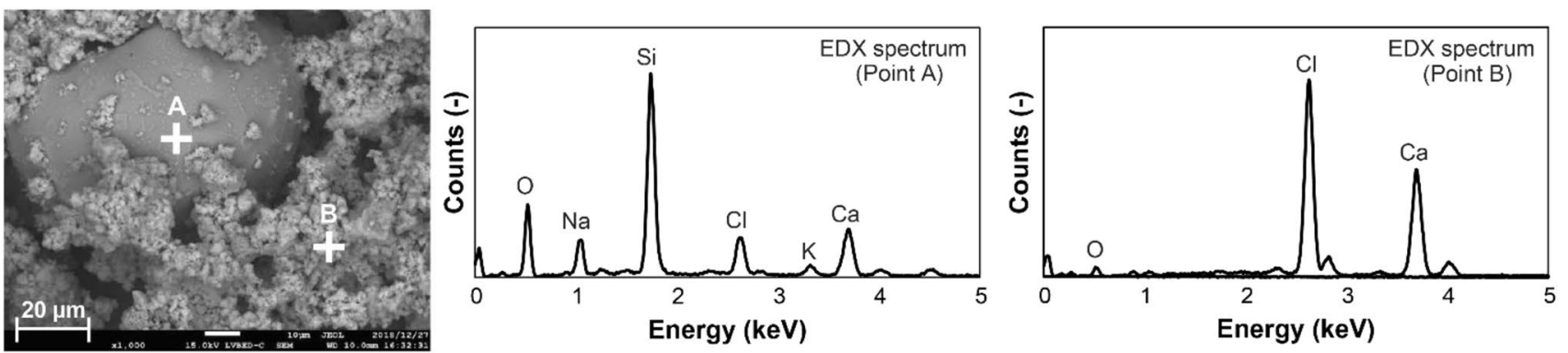

Fig. 4 SEM image and elemental spectra of APC residue particles (white cross mark; analysis point)

Table 4 The $\mathrm{pH}$ and leaching concentrations of toxic metals from raw APC residues $($ mean \pm standard deviation, $n=3)$

\begin{tabular}{lllllll}
\hline Regulated toxic metals & $\begin{array}{l}\mathrm{pH} \\
(-)\end{array}$ & $\begin{array}{l}\mathrm{As} \\
(\mathrm{mg} / \mathrm{L})\end{array}$ & $\begin{array}{l}\mathrm{Cd} \\
(\mathrm{mg} / \mathrm{L})\end{array}$ & $\begin{array}{l}\mathrm{Cr} \\
(\mathrm{mg} / \mathrm{L})\end{array}$ & $\begin{array}{l}\mathrm{Pb} \\
(\mathrm{mg} / \mathrm{L})\end{array}$ & $\begin{array}{l}\mathrm{Se} \\
(\mathrm{mg} / \mathrm{L})\end{array}$ \\
\hline Leaching concentration & $12.0 \pm 0$ & $0.004 \pm 0.0001$ & $\mathrm{~N} . \mathrm{D}$ & $0.24 \pm 0.003$ & $11.7 \pm 0.09$ & N.D \\
Regulated limit & & 0.3 & 0.3 & 1.5 & 0.3 & 0.3 \\
\hline
\end{tabular}

N.D. below detection limit 

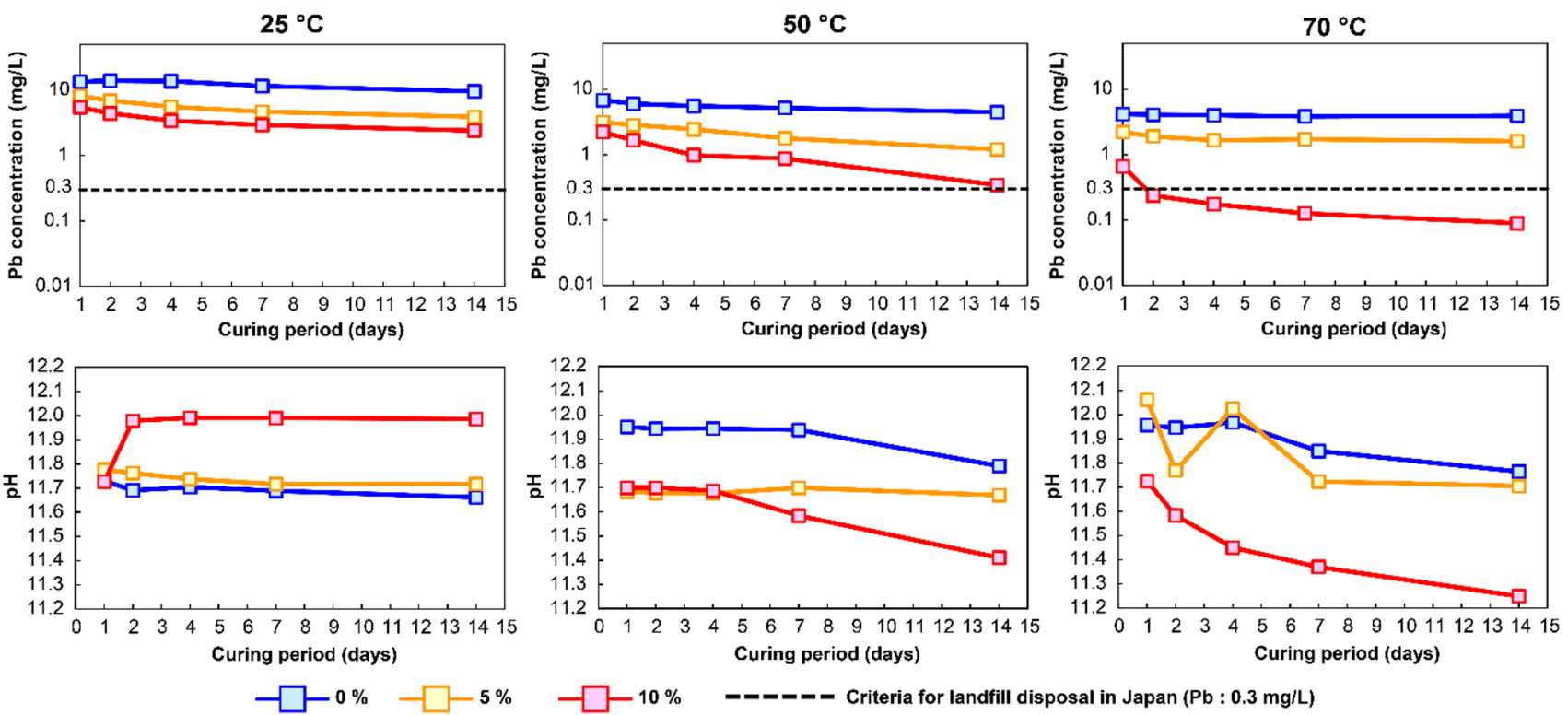

- $10 \% \quad--ー---$ Criteria for landfill disposal in Japan $(\mathrm{Pb}: 0.3 \mathrm{mg} / \mathrm{L})$

Fig. 5 Leaching concentration of lead $(\mathrm{Pb})$ from cured APC residues (diatomite addition: 0,5 , and 10\%)

by factors other than diatomite addition. The possible reasons are discussed in the "Changes in mineralogical characteristics" section with XRD results. A comparison of $\mathrm{Pb}$ leaching by APC residues cured with and without diatomite can quantitatively clarify the impact of diatomite addition on $\mathrm{Pb}$ immobilization. The leaching amount of $\mathrm{Pb}$ was further reduced by $67-90 \%$ and $80-99 \%$ by curing with the addition of 5\% and $10 \%$ diatomite, respectively (orange and red lines in Fig. 5). Consequently, the leaching amount of $\mathrm{Pb}$ dropped below $0.3 \mathrm{mg} / \mathrm{L}$ (Japanese criteria for landfill disposal) after 14 days of curing with the addition of $10 \%$ diatomite at $70{ }^{\circ} \mathrm{C}$.
In these curing experiments, the $\mathrm{pH}$ of the leachate decreased slightly in certain cases. This is mainly ascribed to the reaction of $\mathrm{Ca}(\mathrm{OH})_{2}$ with dissolved diatomite at alkaline $\mathrm{pH}$ and its consumption by the pozzolanic reaction (Dermatas et al. 2005). Figure 6 shows the backscattered electron image and the elemental spectrum of 14-day cured APC residue particles at $70{ }^{\circ} \mathrm{C}$. According to SEM observations, the cylindrical and porous structure of diatomite disappeared, indicating that diatomite reacted with $\mathrm{Ca}(\mathrm{OH})_{2}$ (Sierra et al. 2010). Additionally, APC residue particles appeared to be well connected and formed an aggregate containing $\mathrm{Ca}, \mathrm{Si}$, and other elements via the pozzolanic reaction.
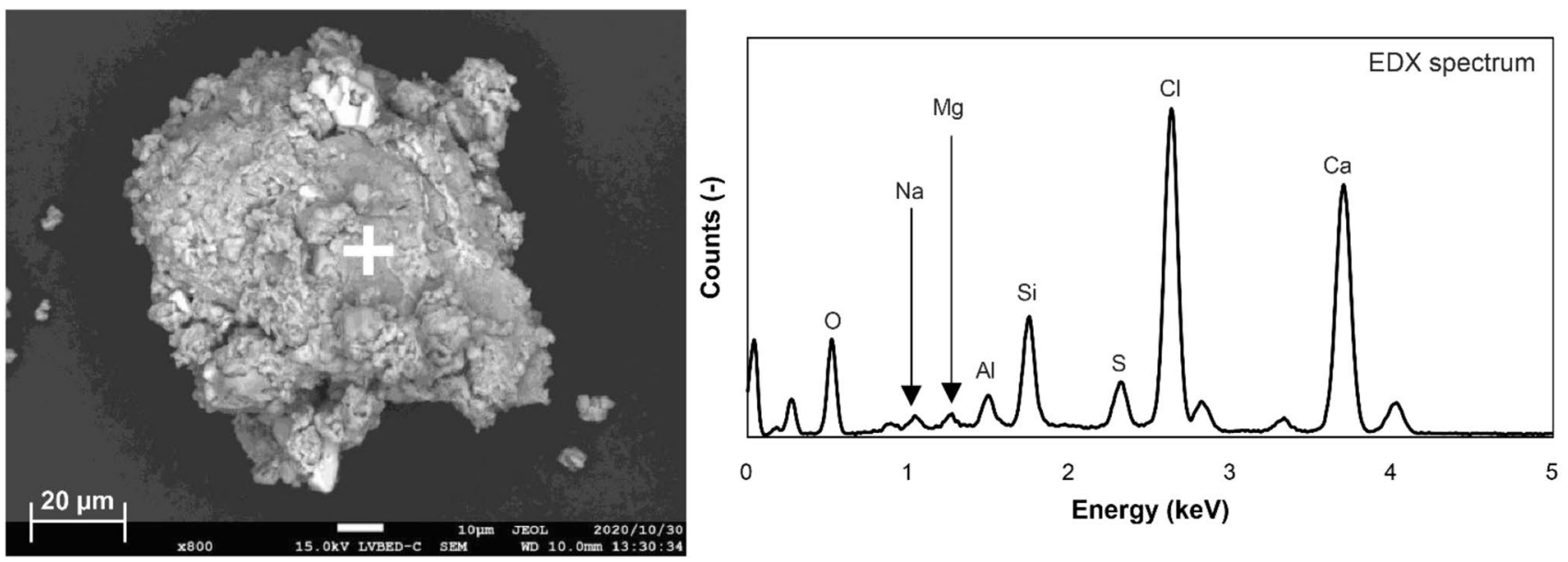

Fig. 6 SEM image and elemental spectrum of cured APC residues following the addition of $10 \%$ diatomite at $70{ }^{\circ} \mathrm{C}$ for 14 days (white cross mark; analysis point) 
Lead solubility heavily depends on $\mathrm{pH}$ owing to amphoteric characteristics (Kosson et al. 1996). Thus, the impact of the pozzolanic reaction on $\mathrm{Pb}$ immobilization remains unclear owing to the decrease in $\mathrm{pH}$ due to curing. To confirm the impact of $\mathrm{pH}$ change on $\mathrm{Pb}$ solubility, the concentration of $\mathrm{Pb}$ leached from raw APC residues at adjusted $\mathrm{pH}$ was measured using leaching tests. In this leaching test, an extractant with different amounts of nitric acid $\left(\mathrm{HNO}_{3}\right)$ and distilled water was used to adjust the $\mathrm{pH}$ at the endpoint. Figure 7 shows the result of the leaching test at $\mathrm{pH}$ adjusted to approximately 11-12. First, the leached concentration of $\mathrm{Pb}$ at a $\mathrm{pH}$ of 11.7 was confirmed because all $\mathrm{pH}$ values of the leachate of 14-day cured APC residues following the addition of $5 \%$ diatomite were approximately 11.7 , as shown in Fig. 5. The results showed that the leached concentration of $\mathrm{Pb}$ from raw APC residues at a $\mathrm{pH}$ of 11.7 was $10.8 \mathrm{mg} / \mathrm{L}$, whereas all leached concentrations of $\mathrm{Pb}$ from 14-day cured APC residues following the addition of 5\% diatomite were significantly lower. The leached concentration of $\mathrm{Pb}$ at a pH 11.2 was also confirmed for comparison with 14-day cured APC residues following the addition of $10 \%$ diatomite at $70{ }^{\circ} \mathrm{C}(0.09 \mathrm{mg} / \mathrm{L})$. The results showed a significant decrease in $\mathrm{Pb}$ leaching at a $\mathrm{pH}$ of $11.2(2.2 \mathrm{mg} / \mathrm{L})$. However, the leaching concentration of $\mathrm{Pb}$ still exceeded $0.3 \mathrm{mg} / \mathrm{L}$ (Japanese criteria for landfill disposal).

Instead of using cement, these results show the feasibility of using diatomite for $\mathrm{Pb}$ immobilization in APC residues. Although $10 \%$ diatomite was added to APC residues in this study, the volume is supposed to be lower than that of cement-based S/S (Sun et al. 2016). The treatment cost is also supposed to be lower than that with cement-based $\mathrm{S} / \mathrm{S}$ as the average cost of diatomite is one-tenth of the average price of Portland cement ( $\mathrm{Li}$ et al. 2019). Notably, the global anthropogenic $\mathrm{CO}_{2}$ emissions generated by the production of Portland cement have reached 9\% (Li et al. 2020). In contrast, the $\mathrm{CO}_{2}$ emissions of mining and processing of diatomite are significantly lower than those of

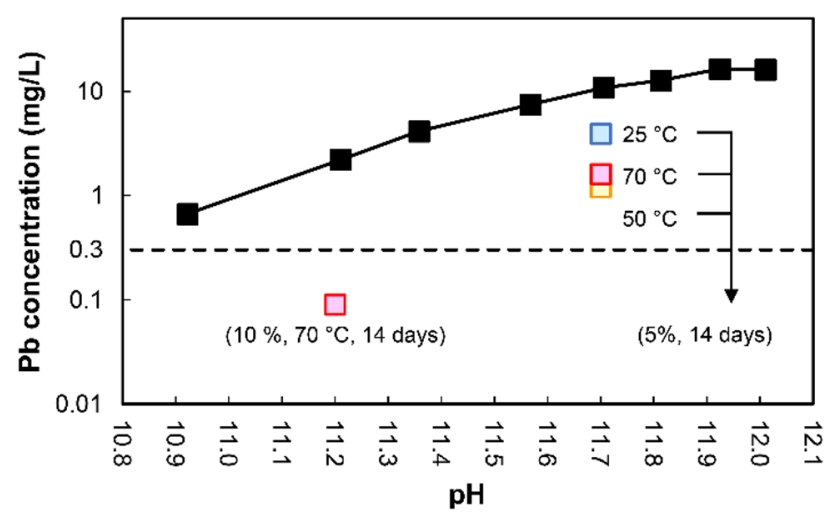

Fig. 7 Leaching concentration of $\mathrm{Pb}$ from raw APC residues at adjusted $\mathrm{pH}$ manufacturing Portland cement ( $\mathrm{Li}$ et al. 2020). Chemical agents are also used for the metal immobilization of APC residues to avoid volume increases. Organic chelating agents are preferred in Japan (Mizutani et al. 2000; Sakanakura 2007) and previous studies showed that they immobilize toxic metals better than other chemical agents (Jianguo et al. 2004; Zhang et al. 2016). In contrast to this advantage, COD components derived from organic chelating agents induce long-term leachate treatment at landfill sites (Higuchi 2015). Using diatomite would reduce the use of chemical agents while suppressing volume increases compared to those with cement. Thus, the treatment proposed in this study seems to be low-cost and environmental-friendly.

To apply this method to other APC residue samples, the relationships among $\mathrm{Pb}$ leaching, diatomite characteristics, and curing conditions should be further investigated. For example, the reactivity of diatomite with $\mathrm{Ca}(\mathrm{OH})_{2}$ (pozzolanic reactivity) plays an important factor in this treatment because the $\mathrm{Ca} / \mathrm{Si}$ ratio affects the physical and chemical properties of C-S-H gel. The cation exchange capacity and specific surface area of C-S-H gel increase as the $\mathrm{Ca} / \mathrm{Si}$ ratio decreases (Suda et al. 2015; Bernard et al. 2021). Luxan et al. (1989) proposed a method to evaluate the pozzolanic activity by measuring the change in the electric conductivity of a saturated $\mathrm{Ca}(\mathrm{OH})_{2}$ solution with pozzolanic materials. In another saturated lime test, pozzolanic activity is quantitatively determined by directly measuring $\mathrm{Ca}(\mathrm{OH})_{2}$ consumed by pozzolanic materials (Mohammed 2017). These indicators of pozzolanic activity seem to be useful in appropriately determining the dose of diatomite and the curing conditions for $\mathrm{Pb}$ immobilization. Therefore, the method for controlling the $\mathrm{Ca} / \mathrm{Si}$ ratio should be investigated further.

\section{Changes in mineralogical characteristics}

Figure 8 shows the XRD patterns of the APC residues cured without diatomite as compared to the raw APC residues. Several new peaks appeared at approximately $10^{\circ} 2 \theta$ after curing. Gypsum $\left(\mathrm{CaSO}_{4} \cdot 2 \mathrm{H}_{2} \mathrm{O}\right)$ was formed in APC residues cured at $25^{\circ} \mathrm{C}$. Ettringite $\left(\mathrm{Ca}_{6} \mathrm{Al}_{2}\left(\mathrm{SO}_{4}\right)_{3}(\mathrm{OH})_{12} \cdot 26 \mathrm{H}_{2} \mathrm{O}\right)$ was formed in all the cured APC residues. These secondary minerals can be formed in APC residues via hydration reaction (Kitamura et al. 2018). Hydrocalumite (known as Friedel's salt $\left.\left(\mathrm{Ca}_{4} \mathrm{Al}_{2} \mathrm{O}_{6} \mathrm{Cl}_{2} \cdot 10 \mathrm{H}_{2} \mathrm{O}\right)\right)$ was also formed in the cured APC residues at $50{ }^{\circ} \mathrm{C}$ and $70{ }^{\circ} \mathrm{C}$ because its formation is favored at relatively high temperatures (Um et al. 2014). Hydrocalumite is formed by a reaction between calcium aluminate hydrate and chloride (Bobirică et al. 2018). This formation immobilizes chloride ions $\left(\mathrm{Cl}^{-}\right)$and releases hydroxide ions $\left(\mathrm{OH}^{-}\right)$(Eq. (6)), suggesting the impact of $\mathrm{Pb}$ solubility. Immobilization of $\mathrm{Cl}^{-}$might reduce the leaching potential of $\mathrm{Pb}$ owing to reduction of forming $\mathrm{Pb}$-chloride complex (Weibel et al. 2018). Because of the release of 


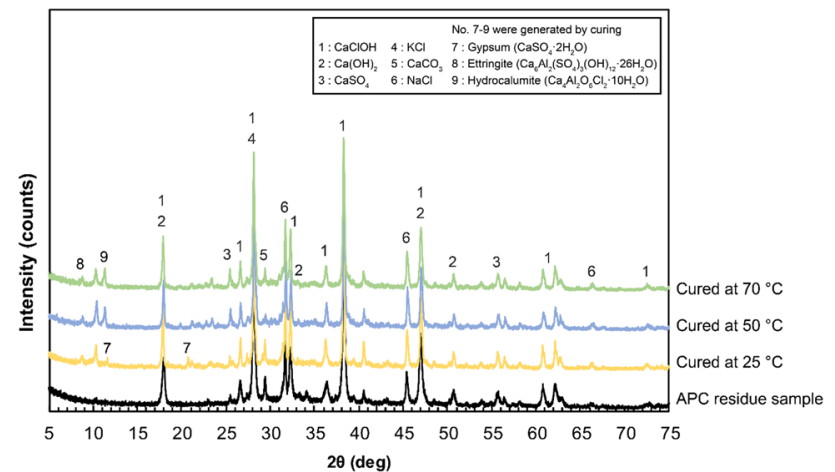

Fig. 8 XRD patterns of raw and cured APC residues without diatomite addition

$\mathrm{OH}^{-}, \mathrm{Pb}$ is precipitated as $\mathrm{Pb}(\mathrm{OH})_{2}$ at $\mathrm{pH} 8-13$ and $\mathrm{Pb}(\mathrm{OH})_{2}$ is dissolved at pH 13-14 (Van Herck et al. 2000; Zhang et al. 2008). In these curing experiments, the $\mathrm{pH}$ of the leachate was 11-12. It is considered that hydrocalumite formation has positive effects on $\mathrm{Pb}$ immobilization when considering the impact of $\mathrm{Cl}^{-}$and $\mathrm{OH}^{-}$ions. Ettringite and hydrocalumite formed in MSWI residues can immobilize $\mathrm{Pb}$ by substitution and absorption reactions (Piantone et al. 2004; Yu et al. 2020). Part of the $\mathrm{Pb}$ in the cured APC residues may be immobilized by these secondary minerals. Further, calcite, which is formed by natural carbonation during the drying process, possibly reduced $\mathrm{Pb}$ leachability in cured APC residues via absorption on their surface and/or incorporation into their crystal structure (Wang et al. 2010). As mentioned in the "Impact of curing of air pollution control residues on lead immobilization" section, the leaching amount of $\mathrm{Pb}$ was reduced by $18-67 \%$ even without diatomite addition. Secondary minerals formed by hydration and carbonation reactions contribute to $\mathrm{Pb}$ immobilization to a certain extent.

$3 \mathrm{CaO} \mathrm{Al}{ }_{2} \mathrm{O}_{3} \mathrm{Ca}(\mathrm{OH})_{2} 12 \mathrm{H}_{2} \mathrm{O}+2 \mathrm{Cl}^{-} \rightarrow 3 \mathrm{CaO} \mathrm{Al}_{2} \mathrm{O}_{3} \mathrm{CaCl}_{2} 12 \mathrm{H}_{2} \mathrm{O}+2 \mathrm{OH}^{-}$

Figure 9 shows the XRD patterns of 14-day cured APC residues following the addition of $10 \%$ diatomite at $70{ }^{\circ} \mathrm{C}$ compared with the raw APC residue sample. The peak intensities of $\mathrm{CaClOH}$ and $\mathrm{Ca}(\mathrm{OH})_{2}$ significantly decreased after curing with diatomite, and were not decreased after curing without diatomite (see Fig. 8). This indicates that $\mathrm{CaClOH}$ and $\mathrm{Ca}(\mathrm{OH})_{2}$ reacted with diatomite for the pozzolanic reaction. In this case, the $\mathrm{pH}$ of leachate only decreased from 11.7 to 11.2 (see Fig. 5) because $\mathrm{CaClOH}$ and $\mathrm{Ca}(\mathrm{OH})_{2}$ remained in cured APC residues even after the pozzolanic reaction. It appeared that the pozzolanic reaction could not be completed by the curing condition, and the added diatomite was not sufficient to consume all of the $\mathrm{CaClOH}$ and $\mathrm{Ca}(\mathrm{OH})_{2}$ in APC residues. In addition, new peaks of pozzolanic phases in the cured APC residues were not confirmed,

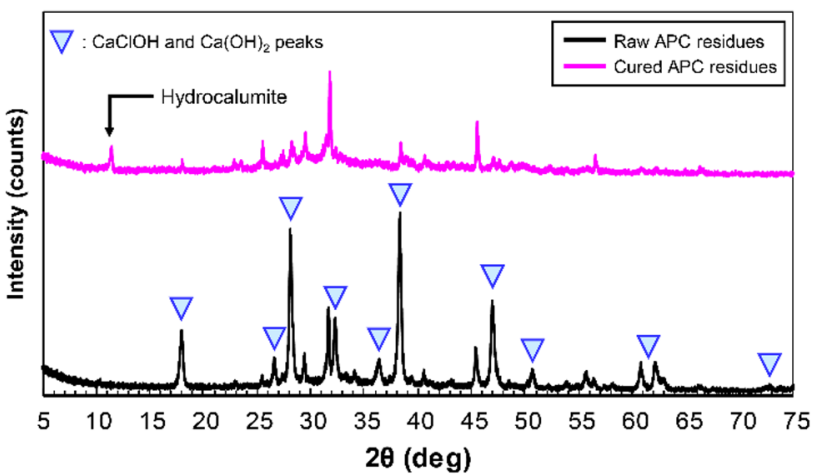

Fig. 9 XRD patterns of raw and cured APC residues with $10 \%$ diatomite at $70{ }^{\circ} \mathrm{C}$ for 14 days

as they were below the detectable level of XRD analysis or incomplete crystallization (Assi et al. 2020). Therefore, a mixture of $\mathrm{Ca}(\mathrm{OH})_{2}$ reagent and diatomite (1:1) following the addition of distilled water was cured at $70{ }^{\circ} \mathrm{C}$ for 14 days to confirm the formation of pozzolanic phases, and then the cured mixture was analyzed by XRD. The results showed the formation of C-S- $\mathrm{H}\left(\mathrm{Ca}_{1.5} \mathrm{SiO}_{3.5} \cdot \mathrm{xH}_{2} \mathrm{O}\right)$ (Fig. 10). The XRD results also showed that hydrocalumite was still formed as a secondary mineral regardless of diatomite addition (see Fig. 9). Hydrocalumite is formed by the hydration reaction between $\mathrm{Al}, \mathrm{Ca}$, and $\mathrm{Cl}$ derived from $\mathrm{APC}$ residues via the curing process (Liu et al. 2018). However, hydrocalumite formation might be limited by the low content of $\mathrm{Al}$ in the raw APC residues (Table 3). Because of the limited formation, decreasing peak intensities of $\mathrm{CaClOH}$ and $\mathrm{Ca}(\mathrm{OH})_{2}$ were not clearly observed in the cured APC residues without the addition of diatomite. According to these results, secondary minerals such as hydrocalumite and pozzolanic phases, such as C-S-H gel, are formed together in APC residues cured with diatomite. Because the peak intensities of $\mathrm{CaClOH}$ and $\mathrm{Ca}(\mathrm{OH})_{2}$ significantly decreased after APC residues were cured with diatomite, the amount of C-S-H gel formation appeared to exceed the amount of hydrocalumite formation. Even though C-S-H gel formation was not detectable in the XRD analysis, the amount was sufficient to immobilize almost all the $\mathrm{Pb}$ in APC residues.

The state of $\mathrm{Pb}$ in $\mathrm{C}-\mathrm{S}-\mathrm{H}$ gel seems to be important for the stability of immobilization. C-S-H gel is a mixture of crystalline and amorphous phases with a layered structure (Guo et al. 2017). Vespa et al. (2014) suggested that C-S-H gel has three potential positions for metal immobilization in its structure: (1) surface complexation, (2) uptake in the interlayer, and (3) incorporation in the $\mathrm{Ca}$ or $\mathrm{Si}$ sheets. The stability of $\mathrm{Pb}$ immobilization in the interlayer and sheets might be higher than that on the surface. However, XRF and $\mathrm{XRD}$ analyses used in this study were insufficient to investigate the $\mathrm{Pb}$ state in $\mathrm{C}-\mathrm{S}-\mathrm{H}$ gel. For example, $\mathrm{XRF}$ analysis 

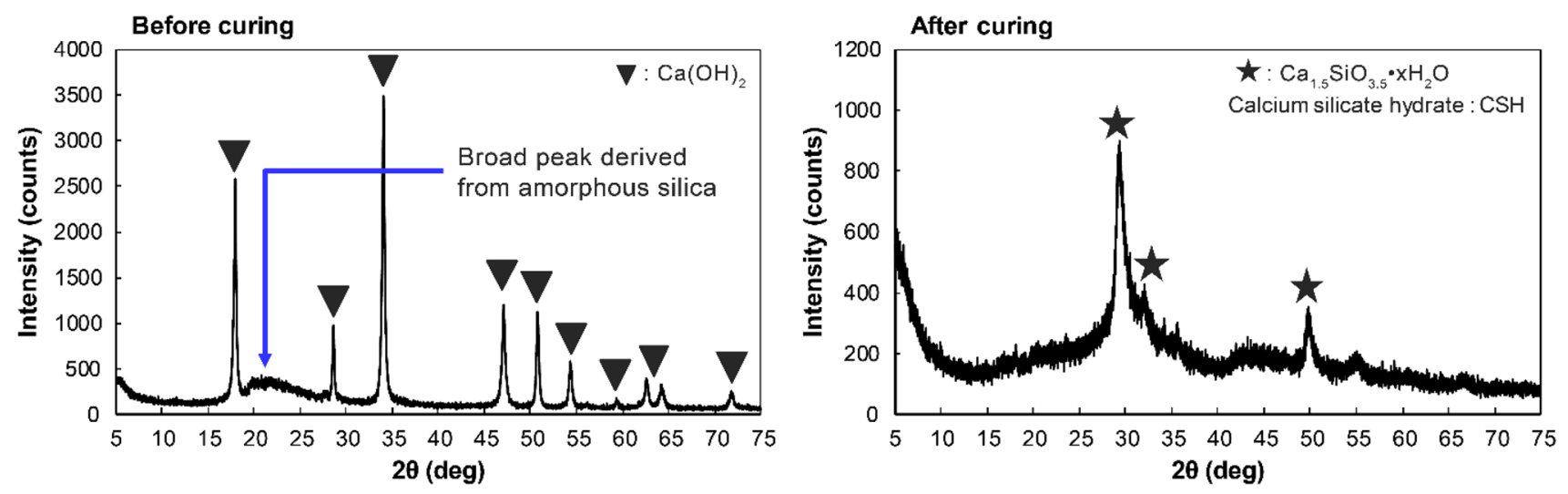

Fig. $10 \mathrm{XRD}$ patterns of mixture of $\mathrm{Ca}(\mathrm{OH})_{2}$ and diatomite before and after curing at $70{ }^{\circ} \mathrm{C}$ for 14 days

does not provide the chemical speciation of the measured elements and XRD analysis only provides a signal from the crystalline fraction of the sample. Therefore, X-ray absorption fine structure (XAFS) spectroscopy using synchrotron radiation is a promising analytical technique for further investigation because it can determine the local coordination chemistry, electric state, and local atomic structure around the absorbing atoms in complex compounds (Contessi et al. 2021).

\section{Chemical forms of lead estimated by sequential chemical extraction}

Figure 11 shows the results of sequential chemical extraction. The chemical forms of $\mathrm{Pb}$ in APC residues changed over the curing period via the addition of $10 \%$ diatomite at $70{ }^{\circ} \mathrm{C}$. The water-soluble $\mathrm{Pb}$ in raw APC residues, which was easily leached out in leaching tests, was $10.3 \%$. Residual $\mathrm{Pb}$, which is insoluble in aqua regia $\left(\mathrm{HNO}_{3}: \mathrm{HCl}=1: 3\right)$ and finally remains in the stable mineral fraction, was the main fraction in raw APC residues (52.4\%). After 1 day of curing, the water-soluble and residual $\mathrm{Pb}$ contents decreased to $1.2 \%$ and $30.5 \%$, respectively. In contrast, carbonateand metal oxide-bound fractions increased as the curing time increased. The carbonate-bound fraction might have increased due to carbonation via atmospheric $\mathrm{CO}_{2}$. Residual $\mathrm{Pb}$ might be decreased by release from the matrix through the curing process because the aluminosilicate matrix of APC residues dissolves under alkaline conditions (Dermatas et al. 2005). Eventually, the leaching amount of $\mathrm{Pb}$ was reduced owing to the decrease in water-soluble $\mathrm{Pb}$ via the pozzolanic reaction.

The main $\mathrm{Pb}$ fractions in the cured APC residues were bound to carbonate, metal oxide, and residual fractions. Because the residual fraction of $\mathrm{Pb}$ is incorporated into the aluminosilicate matrix in APC residues (Huang et al. 2007), it is less soluble even at strong acid conditions.

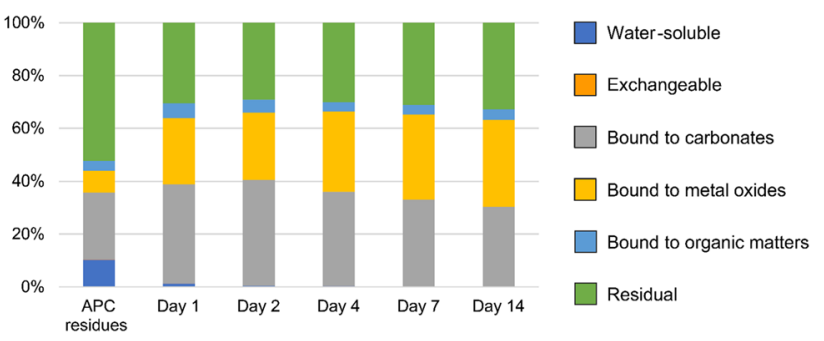

Fig. 11 Fractionation of $\mathrm{Pb}$ in raw and cured APC residues following diatomite addition ( $10 \%$ diatomite cured at $70{ }^{\circ} \mathrm{C}$ for 14 days)

Cerussite $\left(\mathrm{PbCO}_{3}\right)$ and $\mathrm{Pb}$ oxides are probably classified as carbonate-bound and metal oxide-bound fractions (Funatsuki et al. 2012). Bayuseno and Schmahl (2011) suggested that $\mathrm{Pb}$ in MSWI fly ash is less soluble in water because almost $\mathrm{Pb}$ exists as crystalline phases such as $\mathrm{Pb}$ oxides. Even with the low solubility, $\mathrm{Pb}$ leaching might be controlled by $\mathrm{Pb}$ oxides above $\mathrm{pH} 9$ (Astrup et al. 2006). Lead leaching is also controlled by cerussite at $\mathrm{pH}$ 8-10 (Eighmy et al. 1995). In the presence of high $\mathrm{Cl}$ content derived from $\mathrm{CaClOH}, \mathrm{KCl}$, and $\mathrm{NaCl}$ in $\mathrm{APC}$ residues, $\mathrm{Pb}$ might be dissolved by $\mathrm{PbCl}_{2}$ formation at $\mathrm{pH} 0-5$ as well as $\mathrm{Pb}_{2}(\mathrm{OH})_{3} \mathrm{Cl}$ formation above pH 12 (Zhang et al. 2008; Du et al. 2018). Thus, Pb leaching depends on the release of controlling minerals under different $\mathrm{pH}$ conditions (Du et al. 2018). However, the controlling minerals were different in these previous studies because metal speciation in APC residues depends on the chemical potential of elements and flue gas compositions such as contents of chlorine, moisture, sulfur, and inorganic particulates (Chiang et al. 1997; Chen et al. 1998; Youcai et al. 2004; Jiao et al. 2013). In this study, $\mathrm{Pb}$ solubility at $\mathrm{pH} 11-12$ was investigated to confirm the effect of diatomite addition on $\mathrm{Pb}$ immobilization (see Fig. 7). Thus, Pb solubility over a wide $\mathrm{pH}$ range should be further investigated to understand 
the $\mathrm{Pb}$ state in $\mathrm{C}-\mathrm{S}-\mathrm{H}$ gel as well as the stability of $\mathrm{Pb}$ immobilization.

\section{Conclusion}

Diatomite, which is mainly comprised of amorphous silica, was used as a pozzolanic material for $\mathrm{Pb}$ immobilization in APC residues instead of cement. The curing experiment showed that the leaching amount of $\mathrm{Pb}$ from the cured APC residues was reduced as the curing time and temperature increased. Even without diatomite addition, the leaching amount of $\mathrm{Pb}$ after 14 days of curing was reduced by $18-67 \%$ owing to secondary mineral formation (ettringite, hydrocalumite, and calcite). When diatomite was added to APC residues, it reacted with $\mathrm{Ca}(\mathrm{OH})_{2} /$ $\mathrm{CaClOH}$ to form pozzolanic phases such as $\mathrm{C}-\mathrm{S}-\mathrm{H}$ gel. As water-soluble $\mathrm{Pb}$ in APC residues was reduced by the pozzolanic reaction, the leaching amount of $\mathrm{Pb}$ was reduced by $99 \%$ after 14 days of curing with $10 \%$ diatomite at $70{ }^{\circ} \mathrm{C}$. Consequently, the leaching amount of $\mathrm{Pb}$ dropped below $0.3 \mathrm{mg} / \mathrm{L}$ (Japanese criteria for landfill disposal). Thus, the mineralogical characteristics (crystalline and amorphous phases) of APC residues played a substantial role in $\mathrm{Pb}$ immobilization.

Although 10\% diatomite was added to the APC residues in this study, the volume is supposed to be lower than that in cement-based S/S (Sun et al. 2016). From the viewpoint of landfill management, this would also reduce the use of chemical agents while suppressing volume. Even though further studies are required, this method holds potential for the treatment of APC residues as it is low-cost and environmental-friendly.

\begin{abstract}
Author contribution All authors were involved in study design and data interpretation. H. K. carried out the curing experiments, leaching tests, and XRD analysis. M. U. carried out the SEM observation, SEM-EDX analysis, and curing experiments. S. B. carried out the XRF analysis and curing experiments. N. S. carried out the curing experiments and contributed to sample preparation. H. S., T. I., and M. Y. helped supervise the project. H. S., T. I., and M. Y. contributed to the interpretation of the results regarding "the impact of $\mathrm{pH}$ on lead $(\mathrm{Pb})$ solubility," "the impact of pozzolanic reaction on $\mathrm{Pb}$ immobilization," and "the impact of secondary mineral formation on $\mathrm{Pb}$ immobilization," respectively. All authors critically revised the manuscript, commented on the drafts of the manuscript, and approved the final manuscript.
\end{abstract}

Funding This study was supported financially by "the Environment Research and Technology Development Fund (JPMEERF20183002) of the Environmental Restoration and Conservation Agency of Japan" and "JSPS KAKENHI Grant Number 20K19992."

Data availability All data generated or analyzed during this study are included in this published article.

\section{Declarations}

Ethics approval and consent to participate Not applicable.

Consent for publication Not applicable.

Competing interests The authors declare no competing interests.

Open Access This article is licensed under a Creative Commons Attribution 4.0 International License, which permits use, sharing, adaptation, distribution and reproduction in any medium or format, as long as you give appropriate credit to the original author(s) and the source, provide a link to the Creative Commons licence, and indicate if changes were made. The images or other third party material in this article are included in the article's Creative Commons licence, unless indicated otherwise in a credit line to the material. If material is not included in the article's Creative Commons licence and your intended use is not permitted by statutory regulation or exceeds the permitted use, you will need to obtain permission directly from the copyright holder. To view a copy of this licence, visit http://creativecommons.org/licenses/by/4.0/.

\section{References}

Alexander GB, Heston WM, Iler RK (1954) The solubility of amorphous silica in water. J Phys Chem 58:453-455. https://doi.org/ 10.1021/j150516a002

Asakura H, Matsuto T, Inoue Y (2010) Adopted technologies and basis for selection at municipal solid waste landfill facilities constructed in recent years in Japan. Waste Manag Res 28:685-694. https:// doi.org/10.1177/0734242X09345363

Assi A, Bilo F, Zanoletti A et al (2020) Zero-waste approach in municipal solid waste incineration: reuse of bottom ash to stabilize fly ash. J Clean Prod 245:118779. https://doi.org/10.1016/j.jclepro. 2019.118779

Astrup T, Dijkstra JJ, Comans RNJ et al (2006) Geochemical modeling of leaching from MSWI air-pollution-control residues. Environ Sci Technol 40:3551-3557. https://doi.org/10.1021/es052250r

Bayuseno AP, Schmahl WW (2011) Characterization of MSWI fly ash through mineralogy and water extraction. Resour Conserv Recycl 55:524-534. https://doi.org/10.1016/j.resconrec.2011.01.002

Benassi L, Pasquali M, Zanoletti A et al (2016) Chemical stabilization of municipal solid waste incineration fly ash without any commercial chemicals: first pilot-plant scaling up. ACS Sustain Chem Eng 4:5561-5569. https://doi.org/10.1021/acssuschemeng.6b01294

Bernard E, Yan Y, Lothenbach B (2021) Effective cation exchange capacity of calcium silicate hydrates (C-S-H). Cem Concr Res 143:106393. https://doi.org/10.1016/j.cemconres.2021.106393

Bobirică C, Long DT, Parsons MJ et al (2018) Examination of the influence of dissolved halite $(\mathrm{NaCl})$ on the leaching of lead $(\mathrm{Pb})$ from cement-based solidified wastes. J Mater Cycles Waste Manag 20:59-70. https://doi.org/10.1007/s10163-016-0552-6

Bodénan F, Deniard P (2003) Characterization of flue gas cleaning residues from European solid waste incinerators: assessment of various Ca-based sorbent processes. Chemosphere 51:335-347. https://doi.org/10.1016/S0045-6535(02)00838-X

Chang FY, Wey MY (2006) Comparison of the characteristics of bottom and fly ashes generated from various incineration processes. J Hazard Mater 138:594-603. https://doi.org/10.1016/j.jhazmat. 2006.05.099

Chen JC, Wey MY, Su JL, Hsieh SM (1998) Two-stage simulation of the major heavy-metal species under various incineration 
conditions. Environ Int 24:451-466. https://doi.org/10.1016/ S0160-4120(98)00025-7

Chen QY, Tyrer M, Hills CD et al (2009) Immobilisation of heavy metal in cement-based solidification/stabilisation: a review. Waste Manag 29:390-403. https://doi.org/10.1016/j.wasman.2008.01. 019

Chiang K, Wang K, Lin F, Chu W (1997) Chloride effects on the speciation and partitioning of heavy metal during the municipal solid waste incineration process. Sci Total Environ 203:129-140. https://doi.org/10.1016/S0048-9697(97)00140-X

Contessi S, Dalconi MC, Pollastri S et al (2021) Cement-stabilized contaminated soil: understanding Pb retention with XANES and Raman spectroscopy. Sci Total Environ 752:141826. https://doi. org/10.1016/j.scitotenv.2020.141826

Dermatas D, Xu X, Cao X, et al (2005) An evaluation of pozzolanic lead immobilization mechanisms in firing range soils. Proc Int Conf Stabilisation/Solidification Treat Remediat 45-56. https:// doi.org/10.1201/9781439833933.ch8

Du B, Li J, Fang W et al (2018) Characterization of naturally aged cement-solidified MSWI fly ash. Waste Manag 80:101-111. https://doi.org/10.1016/j.wasman.2018.08.053

Durlak SK, Biswas P, Shi J (1997) Equilibrium analysis of the affect of temperature, moisture and sodium content on heavy metal emissions from municipal solid waste incinerators. J Hazard Mater 56:1-20. https://doi.org/10.1016/S0304-3894(97) 00002-2

Eighmy TT, Eusden JD, Krzanowski JE et al (1995) Comprehensive approach toward understanding element speciation and leaching behavior in municipal solid waste incineration electrostatic precipitator ash. Environ Sci Technol 29:629-646. https://doi.org/ 10.1021/es00003a010

Ergün A (2011) Effects of the usage of diatomite and waste marble powder as partial replacement of cement on the mechanical properties of concrete. Constr Build Mater 25:806-812. https://doi.org/ 10.1016/j.conbuildmat.2010.07.002

Escalante-García JI, Sharp JH (1998) Effect of temperature on the hydration of the main clinker phases in portland cements: part $i$, neat cements. Cem Concr Res 28:1245-1257. https://doi.org/10. 1016/S0008-8846(98)00115-X

Fernandez MA, Martinez L, Segarra M et al (1992) Behavior of heavy metals in the combustion gases of urban waste incinerators. Environ Sci Technol 26:1040-1047. https://doi.org/10.1021/es000 $29 \mathrm{a} 026$

Funatsuki A, Takaoka M, Oshita K, Takeda N (2012) Methods of determining lead speciation in fly ash by X-ray absorption finestructure spectroscopy and a sequential extraction procedure. Anal Sci 28:481-490. https://doi.org/10.2116/analsci.28.481

Geysen D, Vandecasteele C, Jaspers M, Wauters G (2004) Comparison of immobilisation of air pollution control residues with cement and with silica. J Hazard Mater 107:131-143. https://doi.org/10. 1016/j.jhazmat.2003.12.001

Gohlke O, Martin J (2007) Drivers for innovation in waste-to-energy technology. Waste Manag Res 25:214-219. https://doi.org/10. 1177/0734242X07079146

Gougar MLD, Scheetz BE, Roy DM (1996) Ettringite and C-S-H portland cement phases for waste ion immobilization: a review. Waste Manag 16:295-303. https://doi.org/10.1016/S0956-053X(96) 00072-4

Greenberg A (1961) Reaction between silica and calcium hydroxide solutions. I. Kinetics in the temperature range to 30 to $85^{\circ} \mathrm{C}$. J Phys Chem 65:12-16. https://doi.org/10.1021/j100819a005

Guo B, Liu B, Yang J, Zhang S (2017) The mechanisms of heavy metal immobilization by cementitious material treatments and thermal treatments: a review. J Environ Manage 193:410-422. https://doi. org/10.1016/j.jenvman.2017.02.026
Higuchi S (2015) Technical transitions and future trends at MSW landfill sites. Mater Cycles Waste Manag Res 26:3-11 ((in Japanese))

Huang SJ, Chang CY, Mui DT et al (2007) Sequential extraction for evaluating the leaching behavior of selected elements in municipal solid waste incineration fly ash. J Hazard Mater 149:180-188. https://doi.org/10.1016/j.jhazmat.2007.03.067

Jianguo J, Jun W, Xin X et al (2004) Heavy metal stabilization in municipal solid waste incineration flyash using heavy metal chelating agents. J Hazard Mater 113:141-146. https://doi.org/ 10.1016/j.jhazmat.2004.05.030

Jiao F, Zhang L, Song W et al (2013) Effect of inorganic particulates on the condensation behavior of lead and zinc vapors upon flue gas cooling. Proc Combust Inst 34:2821-2829. https://doi.org/ 10.1016/j.proci.2012.07.062

Jozewicz W, Gullett BK (1995) Reaction mechanisms of dry Cabased sorbents with gaseous $\mathrm{HCl}$. Ind Eng Chem Res 34:607612. https://doi.org/10.1021/ie00041a022

Jung CH, Matsuto T, Tanaka N, Okada T (2004) Metal distribution in incineration residues of municipal solid waste (MSW) in Japan. Waste Manag 24:381-391. https://doi.org/10.1016/ S0956-053X(03)00137-5

Karlfeldt Fedje K, Ekberg C, Skarnemark G, Steenari BM (2010) Removal of hazardous metals from MSW fly ash-An evaluation of ash leaching methods. J Hazard Mater 173:310-317. https:// doi.org/10.1016/j.jhazmat.2009.08.094

Kastis D, Kakali G, Tsivilis S, Stamatakis MG (2006) Properties and hydration of blended cements with calcareous diatomite. Cem Concr Res 36:1821-1826. https://doi.org/10.1016/j.cemco nres.2006.05.005

Kida A, Noma Y, Imada T (1996) Chemical speciation and leaching properties of elements in municipal incinerator ashes. Waste Manag 16:527-536. https://doi.org/10.1016/S0956-053X(96) 00094-3

Kitamura H, Dahlan AV, Tian Y et al (2018) Impact of secondary generated minerals on toxic element immobilization for air pollution control fly ash of a municipal solid waste incinerator. Environ Sci Pollut Res 25:20700-20712. https://doi.org/10. 1007/s11356-018-1959-5

Kosson DS, Van Der Sloot HA, Eighmy TT (1996) An approach for estimation of contaminant release during utilization and disposal of municipal waste combustion residues. J Hazard Mater 47:43-75. https://doi.org/10.1016/0304-3894(95)00109-3

Li J, Zhang W, Li C, Monteiro PJM (2020) Eco-friendly mortar with high-volume diatomite and fly ash: performance and life-cycle assessment with regional variability. J Clean Prod 261:121224. https://doi.org/10.1016/j.jclepro.2020.121224

Li J, Zhang W, Li C, Monteiro PJM (2019) Green concrete containing diatomaceous earth and limestone: workability, mechanical properties, and life-cycle assessment. J Clean Prod 223:662679. https://doi.org/10.1016/j.jclepro.2019.03.077

Liu X, Zhao X, Yin H et al (2018) Intermediate-calcium based cementitious materials prepared by MSWI fly ash and other solid wastes: hydration characteristics and heavy metals solidification behavior. J Hazard Mater 349:262-271. https://doi.org/ 10.1016/j.jhazmat.2017.12.072

Lombardi L, Carnevale E, Corti A (2015) A review of technologies and performances of thermal treatment systems for energy recovery from waste. Waste Manag 37:26-44. https://doi.org/ 10.1016/j.wasman.2014.11.010

Luxan MP, Madruga F, Saavedra J (1989) Rapid evaluation of pozzolanic activity of natural products. Cem Concr Res 19:63-68. https://doi.org/10.1016/0008-8846(89)90066-5

Mizutani S, van der Sloot HA, Sakai S (2000) Evaluation of treatment of gas cleaning residues from MSWI with chemical agents. Waste Manag 20:233-240. https://doi.org/10.1016/S0956053X(99)00317-7 
Mohammed S (2017) Processing, effect and reactivity assessment of artificial pozzolans obtained from clays and clay wastes: a review. Constr Build Mater 140:10-19. https://doi.org/10. 1016/j.conbuildmat.2017.02.078

Montagnaro F, Salatino P, Scala F et al (2003) Assessment of ettringite from hydrated FBC residues as a sorbent for fluidized bed desulphurization. Fuel 82:2299-2307. https://doi.org/10.1016/ S0016-2361(03)00177-7

Piantone P, Bodenan F, Chatelet-Snidaro L (2004) Mineralogical study of secondary mineral phases from weathered MSWI bottom ash: implications for the modelling and trapping of heavy metals. Appl Geochemistry 19:1891-1904. https://doi.org/10. 1016/j.apgeochem.2004.05.006

Polettini A, Pomi R, Sirini P, Testa F (2001) Properties of Portland cement - stabilised MSWI fly ashes. J Hazard Mater 88:123-138. https://doi.org/10.1016/S0304-3894(01)00292-8

Quina MJ, Bordado JC, Quinta-Ferreira RM (2008) Treatment and use of air pollution control residues from MSW incineration: an overview. Waste Manag 28:2097-2121. https://doi.org/10.1016/j. wasman.2007.08.030

Quina MJ, Bordado JCM, Quinta-Ferreira RM (2010) Chemical stabilization of air pollution control residues from municipal solid waste incineration. J Hazard Mater 179:382-392. https://doi.org/ 10.1016/j.jhazmat.2010.03.016

Ren Z, Gao H, Zhang H, Liu X (2014) Effects of fluxes on the structure and filtration properties of diatomite filter aids. Int $\mathrm{J}$ Miner Process 130:28-33. https://doi.org/10.1016/j.minpro.2014.05.011

Sakanakura H (2007) Formation and durability of dithiocarbamic metals in stabilized air pollution control residue from municipal solid waste incineration and melting processes. Environ Sci Technol 41:1717-1722. https://doi.org/10.1021/es062077e

Shim Y, Rhee S, Lee W (2005) Comparison of leaching characteristics of heavy metals from bottom and fly ashes in Korea and Japan. Waste Manag 25:473-480. https://doi.org/10.1016/j.wasman. 2005.03.002

Sierra EJ, Miller SA, Sakulich AR et al (2010) Pozzolanic activity of diatomaceous earth. J Am Ceram Soc 93:3406-3410. https://doi. org/10.1111/j.1551-2916.2010.03886.x

Song GJ, Kim KH, Seo YC, Kim SC (2004) Characteristics of ashes from different locations at the MSW incinerator equipped with various air pollution control devices. Waste Manag 24:99-106. https://doi.org/10.1016/S0956-053X(03)00073-4

Suda Y, Saeki T, Saito T (2015) Relation between chemical composition and physical properties of C-S-H generated from cementitious materials. J Adv Concr Technol 13:275-290. https://doi.org/10. $3151 /$ jact.13.275

Sun X, Li J, Zhao X et al (2016) A review on the management of municipal solid waste fly ash in American. Procedia Environ Sci 31:535-540. https://doi.org/10.1016/j.proenv.2016.02.079

Tessier A, Campbell PGC, Bisson M (1979) Sequential extraction procedure for the speciation of particulate trace metals. Anal Chem 51:844-851. https://doi.org/10.1021/ac50043a017

Um N, Nam S-Y, Thriveni T, Ahn J-W (2014) Effect of accelerated carbonation on the mineral phase of alkaline inorganic waste. Resour Process 61:39-48. https://doi.org/10.4144/rpsj.61.39

Van Der Sloot HA, Kosson DS, Hjelmar O (2001) Characteristics, treatment and utilization of residues from municipal waste incineration. Waste Manag 21:753-765. https://doi.org/10.1016/S0956053X(01)00009-5
Van Herck P, Van Der Bruggen B, Vogels G, Vandecasteele C (2000) Application of computer modelling to predict the leaching behaviour of heavy metals from MSWI fly ash and comparison with a sequential extraction method. Waste Manag 20:203-210. https:// doi.org/10.1016/S0956-053X(99)00321-9

Vespa M, Dähn R, Wieland E (2014) Competition behaviour of metal uptake in cementitious systems: an XRD and EXAFS investigation of Nd- and Zn-loaded $11 \AA$ tobermorite. Phys Chem Earth 70-71:32-38. https://doi.org/10.1016/j.pce.2014.01.001

Wan X, Wang W, Ye T et al (2006) A study on the chemical and mineralogical characterization of MSWI fly ash using a sequential extraction procedure. J Hazard Mater 134:197-201. https://doi. org/10.1016/j.jhazmat.2005.10.048

Wang L, Jin Y, Nie Y (2010) Investigation of accelerated and natural carbonation of MSWI fly ash with a high content of Ca. J Hazard Mater 174:334-343. https://doi.org/10.1016/j.jhazmat.2009.09. 055

Weibel G, Eggenberger U, Kulik DA et al (2018) Extraction of heavy metals from MSWI fly ash using hydrochloric acid and sodium chloride solution. Waste Manag 76:457-471. https://doi.org/10. 1016/j.wasman.2018.03.022

Weibel G, Eggenberger U, Schlumberger S, Mäder UK (2016) Chemical associations and mobilization of heavy metals in fly ash from municipal solid waste incineration. Waste Manag 62:147-159. https://doi.org/10.1016/j.wasman.2016.12.004

Xu S, Wang J, Jiang Q, Zhang S (2016) Study of natural hydraulic lime-based mortars prepared with masonry waste powder as aggregate and diatomite/fly ash as mineral admixtures. J Clean Prod 119:118-127. https://doi.org/10.1016/j.jclepro.2016.01.069

Youcai Z, Stucki S, Ludwig C, Wochele J (2004) Impact of moisture on volatility of heavy metals in municipal solid waste incinerated in a laboratory scale simulated incinerator. Waste Manag 24:581-587. https://doi.org/10.1016/j.wasman.2004.01.004

Yu S, Du B, Baheiduola A et al (2020) HCB dechlorination combined with heavy metals immobilization in MSWI fly ash by using n-Al/ $\mathrm{CaO}$ dispersion mixture. J Hazard Mater 392:122510. https://doi. org/10.1016/j.jhazmat.2020.122510

Zacco A, Borgese L, Gianoncelli A et al (2014) Review of fly ash inertisation treatments and recycling. Environ Chem Lett 12:153-175. https://doi.org/10.1007/s10311-014-0454-6

Zhang B, Zhou W, Zhao H et al (2016) Stabilization/solidification of lead in MSWI fly ash with mercapto functionalized dendrimer Chelator. Waste Manag 50:105-112. https://doi.org/10.1016/j. wasman.2016.02.001

Zhang Y, Jiang J, Chen M (2008) MINTEQ modeling for evaluating the leaching behavior of heavy metals in MSWI fly ash. J Environ Sci 20:1398-1402. https://doi.org/10.1016/S1001-0742(08)62239-1

Zheng R, Ren Z, Gao H et al (2018) Effects of calcination on silica phase transition in diatomite. J Alloys Compd 757:364-371. https://doi.org/10.1016/j.jallcom.2018.05.010

Publisher's note Springer Nature remains neutral with regard to jurisdictional claims in published maps and institutional affiliations. 